\title{
Real Language, Real Literature: Problems of Authenticity in Modern Finnic Minority Literatures
}

\begin{abstract}
Alongside the nation-state languages Finnish and Estonian, their sister varieties - such as Meänkieli in Sweden, Kven in Norway, Karelian in Finland and Russia, Veps in Russia, or Võro in southern Estonia - are now either recognized or striving for recognition as minority languages. Developing literary standards and literatures raises questions of authenticity: is language a naturally existing part of ethnic identity or something that must be cultivated and formally studied? Should literature offer realistic depictions of the life and multilingual language use of minorities, or should it serve the puristic goals of language planning and language-based identity building? The ways in which literary and mimetic multilingualism can relate to the linguistic reality of minorities are still in need of further research.
\end{abstract}

Keywords: authenticity, Estonia, language planning, minority literatures, multilingualism, Russia, Scandinavia

\section{A language for a nation}

The national awakenings prompted by Romantic nationalism in the nineteenth century led to the standardization of many Finno-Ugric languages: first in the emerging state language projects, and then at different points of time into the late twentieth century, also involving many Finno-Ugric minorities. The goals of these processes were not only practical and political but also aesthetic: to create a language for artistic expression.

Romantic nationalism saw language as a supra-individual product of nature and the Volksgeist. The Romantic pioneer authors of emerging nations used "a subaltern vernacular in order to demonstrate and celebrate its literary capabilities" (Leerssen 2013, 13). Paradoxically, however, they had to overlook the processes of language planning and forget the fact that the language they used was not a direct representation of the authentic vernacular but an artefact, as alien to the common people as were the Western forms and genres in which it was used. This, of course, was in line with the general folklorism (or "fake-lorism"; see 
Bendix 2009, 176-187) of these national projects, inventing the tradition and then forgetting how the tradition was invented.

Both in Scandinavia and in Russia, the literatures of the emerging or recently acknowledged ethnic minority languages are still struggling with the same problems: the hidden discrepancy between authenticity and language planning. For Veps, a Finnic minority language in north-western Russia, since the turn of the 1990s a literary language has existed, but many older speakers feel that this new language is "not the real thing":

minun tatam sanub kaiken aigan sinä pagižed verhal kelel, sikš ku minä sindai en el'genda, en tea miččel kelel sinä pagižed, no ed vepsän kelel, - - erased sanad potomu što hii ii tekoi, neglik da sebranik da, ken om sebranik, a podrušk a no podrušk

“My father keeps telling me: you speak in a foreign language, because I don’t understand you. I don't know which language you are speaking, but it's not Veps. - - Because there are certain words they [the older generation] don't know, neglik [hedgehog] and sebranik [friend], and ... who is a sebranik? Oh, podrušk [Russian podružka 'girlfriend'], well podrušk." (Puura et al. 2013, 141; translation modified here)

For speakers who resist the idea of written culture, the unified and homogenized written standard just does not feel right, as in this example from a study on the Võro language in southern Estonia:

umma lehte tuud tuud ma piä hindä jaos ümbre tõlkma tuu om väega määndseski kohitsedu keeleh üldiselt kirotõdu [...]

"Uma Leht (the Võro-language bimonthly), that, that I must translate for myself, it's very much, written in a kind of castrated language in general” (Koreinik 2013, 91; translation modified here)

Facing this paradox, only a few authors try to bridge the gap between the ethnolinguistic assumption (the idea that there is a simple one-to-one correspondence between identity and language; see e.g. Blommaert, Leppänen, and Spotti $[2012,4])$ and the standard-language ideology, which claims that not even native speakers can master their language without formal education (Milroy 2001, 537). The only both explicit and elegant attempt to do so that I have managed to find comes from Bengt Pohjanen, who writes in Meänkieli, a Far-Northern Finnish variety in Sweden: ${ }^{1}$

1 Translations in this article are my own unless otherwise indicated. 


\begin{abstract}
Ennää mie en halvaa olla viehraana toisten toelisuuessa. Mie hääyn oppia suomen, niin, sitä suomea, jota met puhuma ja jota ei vielä ole olemassa, mutta jota mie kannan syämessä sikiönnä, joka jo kauon oon oottanu minun hajoaamista ja sen syntymistä. Enhään mie sitä vielä käsitä, ette mie halvaan synnyttää minun äitinkielen. Samaan se sille, ette mie olen keskonen, mutta minun kielen synnyttäjä mie halvaan olla itte. [...] Minun kieli halvaa ulos niinku kaikki kielet halvaava, syyreä saahmaan, henkhiin ja haisthaan, anthaan kukile nimiä, kaloile kans, selithään juttuja ja tinkaahmaan, lauhlaan ja itkheen, olheen muitten kielten roikassa. Mie halvaan synnyttää kielen ja sitte auttaa muitaki synnythään. Mie halvan kielen paanmuskaksi. (Pohjanen 2009, 190-191)
\end{abstract}

[I don't want to be a guest in the reality of others any more. I must learn Finnish, yes, the kind of Finnish that we speak, the language which doesn't exist yet but which I'm carrying in my heart like a child that has long waited for me to go into labour and give birth to it. I don't understand yet that I want to give birth to my mother tongue. Never mind that I was prematurely born, I myself want to be the one who gives birth to my language. [...] My language wants to come out like all languages do, to get oxygen, to breathe and to smell, to give names to flowers, and to fish, too, to explain things and to barter, to sing and to cry, to be a language among other languages. I want to give birth to the language and then help others give birth, too. I want to be the midwife of language.]

The quotation is from Pohjanen's autobiographical novel Jopparikuninkhaan poika [The Son of the Smuggler King], the story of the protagonist's childhood and youth in northern Sweden near the Finnish border, starting with his birth with the help of two competing local midwives. The physical and biological reality of childbirth in a remote village in the 1940s is contrasted with the literary connotations of the expression "guest in reality" - Gäst hos verkligheten, the title of a famous philosophical novel by the Swedish author Pär Lagerkvist. In Pohjanen's text, this "reality of others" is a literary, theoretical one, while the author's native language is a living being, physically real. At the same time, however, in folk-linguistic thought only written and standardized languages are "real."

With the midwife metaphor, Pohjanen skilfully combines the two opposing aspects of minority-language planning: the language has the right to be born because it already exists like an unborn child, but the language cannot be born without the active agency of the midwife, the language activist. Furthermore, the quotation illustrates a typical feature of endangered languages: writing in the language easily turns into writing about the language and language-related issues - the choice of language in itself is a political act and the text has an explicit language-political agenda. This also means dealing with the reality of multilingualism, finding a place for the language "among other languages" [muitten kielten roikassa]. 


\section{Keeping it our language: Linguistic purism}

The Romantic nationalist language-planning projects in Eastern Europe were also characterized by purism, the avoidance of foreign elements. Thomas (1991, 75-83 [see also Brunstad 2003, 57-58; Kamusella 2009]) distinguishes six orientations of purism in language planning:

- xenophobic (foreign influences are bad in general),

- elitist (the language of educated city elites is inherently better),

- ethnographic (authentic dialects of the common people are inherently better),

- reformist (a new language for a new society must be created, also to signal a break with the colonial past),

- playful purism (language planning as an aesthetic game), and

- archaizing (focus on a "golden age" in the national past).

In one form or another, all of these have been present in the Finno-Ugric language-planning movements, although - the traditions of literary and elite language use being very thin or non-existent - the "elitist" and "archaizing” orientations have had no more than indirect and abstract representations.

It is also important to note how these aspects of purism relate to the opposition of authentic vs constructed. The history of Finno-Ugric literatures offers us many examples of both purism-by-construction (as in the Veps example above) and puristic archaisms connected with ethnographic authenticity. Again, we meet the paradox of folklorism, or what Gayatri Spivak has called strategic essentialism (for an insightful critique, see Lee [2011]): accepting and appropriating an "artificial" ethnocultural identity for political purposes.

Moreover, it must be noted that linguistic purism is often relative. It relates to and targets a certain language as its "enemy," disregarding or repositioning other languages. In the codification process of Modern Standard Finnish in the nineteenth century, linguistic purism mainly targeted Swedish influences, while Eastern Finnish or Karelian dialect words were perceived as authentic (even if they were originally Russian loanwords). Similarly, while Estonian language planning is widely known for its lexical purism and neologisms such as arvuti "computer" (from the verb arvuta- "count, calculate"), for Võro activists in southern Estonia, puutri, a nativized form of the internationalism computer, is more "authentic" than the Standard Estonian word. For many minority languages today, it is the nation-state language that poses the primary threat, while other international lingua francas, English in particular, may even be perceived as "allies."

Debates on puristic language planning are symptomatic of the situation of many minority languages today, and the question of whether the language "loses 
its cultural value with too many foreign words" (Garland 2008, 115) is often heatedly discussed. Borrowing from the majority language is an easy solution for modern bilingual speakers; but, especially in laymen's eyes, abundant loanwords are understood as a signal of inferiority ("they don't even have a word of their own for X"). On the other hand, excessively puristic language planning will turn the language into something artificial or "castrated," or musealize it into a language for old people and old things. The gatekeeper effect, with traditional speakers jealously protecting the language from younger generations, can be observed with many minority languages in Russia in particular (see Scheller 2011, 85).

\section{The "real" presence of the other language in literature: From symbolic to macaronic}

Literature has played and will play a key role in the promotion, image-construction, and maintenance of numerous modern minority languages. In fact, many of them have no role at all or merely symbolic uses in administration and education. Moreover, their media presence may be very restricted, so that literary and artistic uses are practically the only public domain open for them.

While the Romantic nationalist language and literature projects were characteristically monolingual, today's minorities face a different challenge. Creating a monolingual world in literature is only possible in certain genres such as historical fiction. Any kind of text which relates to the linguistic reality of today must pay attention to the presence of other languages in the life of modern minorities. How this is expressed in the text can be analysed in terms of various dimensions of form and function.

Where function is concerned, the explicit presence of other languages in the text can express a subversive, emancipatory agenda, explicitly thematizing linguistic oppression, as in this excerpt from a novel by Alf Nilsen Børsskog, a pioneer of Kven literature. (Kven, like Meänkieli, is a Far-Northern Finnish variety, spoken in Norway and recently recognized as a minority language.) The protagonists, a group of Kvens, sitting in a hideout in the mountains during World War II, are passing their time by chatting about everything between heaven and earth:

Enkelitten kuorolaulusta kuosuvaarantakalaiset siirrythiin maalishiin asioihin, ko het alethiin puhuskelehan Kentän kouluhuonheesta, koulumiehestä, ja häne opettamisesta, josta het ei olheet ymmärtänheetkhään niin paljookhaan. "Eihän se mies puhunukhaan meiđän ommaa kieltä,” sanoi Anni. Kaikki heilä oli jäänny oppimatta: Raamatunhistoria, Klaarikka, norjan kieli, äiđinkieli ja vieläpä räkinkiki. Kuka heistä pikkulapsista olis saattanu tiettäät 
mitä se fem pluss fem oli. "Hyvin met tiesimä ette viisi ja viisi oli kymmenen. Mutta kuka viheliäisen viisas olis saattanu arvata mitä tuo fem pluss fem oli?”” kysyi Anni. (Nilsen-Børss$\operatorname{kog} 2004,198)$

[From the choral song of angels, the people behind Kuosuvaara Fell went on to worldly affairs and started talking about the schoolhouse at Kenttä, the teacher and his teaching, of which they hadn’t understood very much. "He didn’t even speak our language," Anni said. They had missed everything: Bible history, the Catechism, the Norwegian language, their mother tongue, and even mathematics. Who of them, little kids, could have known what fem pluss fem (five plus five) was. "We knew very well that five and five makes ten. But who was smart enough to guess what that fem pluss fem means?” Anni asked.]

This is a typical example of how minority literatures thematize linguistic oppression. The foreign elements are sparse and symbolic. We do not get a realistic representation of what happened between the Norwegian-speaking teacher and the Kven children; a short token phrase in another language is enough to convey the idea of the language barrier. In Meir Sternberg's (1981) taxonomy, this kind of multilingualism moves between "homogenizing convention" (everything is translated into the language of narration) and "selective reproduction" (only a few examples of the other language are given).

At the other end of the continuum of literary multilingualism, we have what Sternberg (1981) calls "vehicular promiscuity" and what is traditionally often called macaronism or, sloppily, "mixed language." The other language is present in so many insertions that it is difficult to determine which language is the "matrix" one, and sometimes even grammatical elements or constructions can be mixed or intertwined. Macaronism is traditionally used in puns and inside jokes of multilingual groups, from European academic traditions of mixing Latin with the local vernacular to the multilingual folklore of minority groups (see Verschik 2013).

In the following Veps chastushka, published in a folklore collection, almost all lexical words are Russian, while the grammar is mostly Veps or hybridized (as in ot butylkad "from the bottle," with the Russian preposition ot and the Veps partitive case ending $-d$ ). The point here is not that the Veps would not be able to express these things in their own words; rather, this is a multilayered joke playing both on the omnipresence of Russian and the ability of Veps speakers to combine two languages.

taŕi, taŕi bi kolhozas

d'isćipl'inan nav́et't'a.

predśedat'el'ad kolhoza

ot butilkad otv́et't’a. (Zajceva and Mullonen 1969, 173; Russian elements in italics) 
[Necessary, necessary it would be in the collective farm

to introduce discipline,

to wean the president of the collective farm

from the bottle.]

In the context of language endangerment, however, macaronism may assume another role, creating caricatures of assimilation: "look what has happened to our language!” This poem by Olga Moshnikova was published on a website for Karelian teachers and language activists, opastajat.net:

Oppizin paista nygözeh moudah,

kui karjalan rahvas ven'akse murdau.

Olis vai himo säilyttiä kieli,

eihäi sit nagrettas oma hieru.

Gu tulethäi kunne,

sit "zdraste vam", kuuluu.

Pagin luadu ven’akse muuttuu.

Vahnat, gu bluaznat, muodoillah kaikkeh,

vai olis havahtuakseh, gu tuulen hattu.

Oppiet vai duumaija - mi on kummu:

Kak dela podruugu, čto novogo kuuluu?

Tänäpäi televizoras on hyvä fil'mu, tule hos gostih da pozvoni kerdu.

Toizel kerral ob'azatel'no tulen, a tänäpäi en voi, zan'atoi olen.

Utrečkom avtoubusal gorodah ajan,

Produktua, podarkua lapsile ostan.

Nu ladno, poka. Sčastlivo ajua.

Muuzale piivuo ne zabud' ostua.

Kehvelin boleznii meih nygöi pristuanii.

Ved' umnoit dai gramotnoit bili bi kaikin, Hinnan dai sprosan ičele znaem.

Mikse sit tuskas žizn' protekaet? (Moshnikova n.d.; Russian elements in italics)

[I tried to speak in today's way,

the Russian lingo which Karelians are speaking.

If only one would want to maintain one's own language,

and not be the laughing stock of the whole village. 


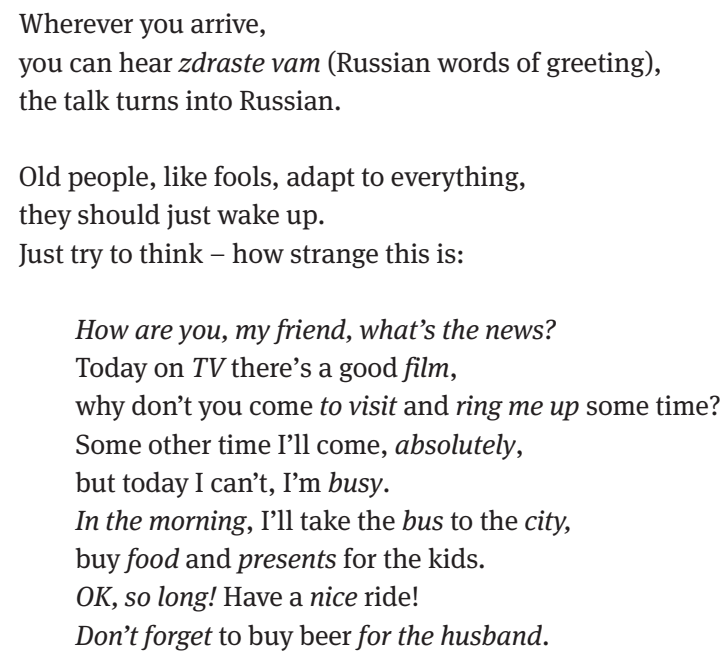

What a darned disease we have caught.

We should all be wise and literate, we know our price and the demand for us.

Why is our life going by in anxiety?]

The markedly Russian elements of the poem are not easy to distinguish from established Russian loanwords such as gost'ih "to visit" or piivo "beer," which were used by Karelian speakers even a hundred years ago. The most obvious Russian loans are greetings and discourse words (čto novogo? "what's the news?") or verb phrases showing Russian inflections (ne zabud' "don't forget”). The middle part of the poem, marked with indentation, illustrates modern Karelian language use, and the last lines, with the narrator also switching to the mixed code, signal a kind of resignation.

\section{Accommodating mimetic multilingualism}

The two previous examples illustrate the dark side of multilingualism as experienced by speakers of endangered languages: linguistic oppression and low prestige. However, modern minorities are often not only bilingual but multilingual. Languages other than the local minority or dominant ones do not represent an immediate threat, which means that they can be used for aesthetic goals. The following example, from a poem by the Vorro-language poet Contra (Margus Kõnnula), includes a short phrase in English and the name of a famous Danish football goalkeeper: 


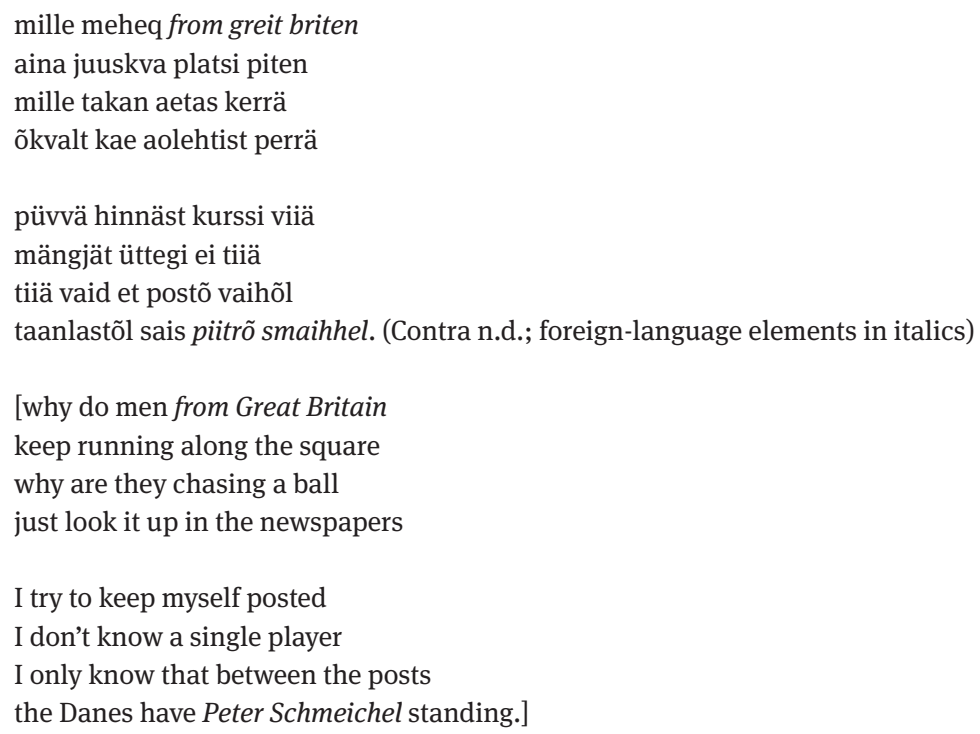

Note that the foreign names are written with small letters and orthographically transcribed, and Schmeichel's given name is "nativized" as "piitrõ." What we see here is an aesthetic game of finding rhyme words which would be impossible in Standard Estonian. Although the tradition of Estonian poetry is very rich in the highly skilled use of rhyme and metre, Standard Estonian for phonological reasons has very few word forms ending with $-n$ (to rhyme with Britain) and no -aih- sound sequences (to rhyme with Schmeichel). In these verses, Contra humorously demonstrates how South Estonian rhymes with foreign words where Standard Estonian cannot.

We can also read this poem as a miniature illustration of how English and other major lingua francas can serve to relativize the importance of the dominant language. These foreign items embedded in the text provide a vantage point from which South Estonian, formerly considered "just a dialect," is now in no way inferior to Standard Estonian but a language in the company of other languages ("muitten kielten roikassa," as Bengt Pohjanen put it in Meänkieli). So, finally, what this example illustrates is increased awareness of multilingualism on a more abstract level.

Multilingualism in literature was long understood as directly reflecting reallife multilingualism. Even in our own time, minority and migrant literatures are often subject to an authenticity expectation: in the same way as women authors in the nineteenth century were supposed to represent a "woman's perspective," migrant and minority authors have long been expected to deliver an ethnograph- 
ically authentic representation of their linguistic environment (see e.g. Nilsson 2013, 52-61).

Looking at modern Finnic minority literatures, however, we hardly find any realistic representations of everyday multilingualism. And, notably, this is the case despite the strong traditions of realism and the emancipatory agenda of many minority literatures. Instead of constant code-switches and ample nonce loanwords, in modern Finnic minority literatures we see multilingualism sparsely and symbolically represented, as in the earlier Kven example, or an exaggerated caricature of multilingual communication, as in the Karelian example - both in the service of revitalization or fighting linguistic oppression. Alternatively, minority authors, like all others, can turn their back on linguistic realism and freely use multilingualism for aesthetic goals. We might draw the conclusion that multilingualism in minority literatures has precious little to do with real languages or their use.

Even if analysing the examples discussed here needs special linguistic expertise, the real challenge probably lies in understanding and describing the aesthetic and mimetic aspects of literary multilingualism - in relation to prevailing traditions, conventions, and expectations of the target audiences, and to the literary and linguistic cultures in which the texts were produced. These cultures, in turn, differ in different countries. Post-Soviet Russia with its general glorification of the Russian language (despite lip-service to traditional indigenous cultures) is ideologically different from the Nordic countries, where assimilationist policies have, in the late twentieth century, largely given way to more generous attitudes towards minorities, and from post-Soviet Estonia with its strongly language-based nationalism. Multilingual individuals do not perceive themselves as representing a phenomenon in general terms: their multilingualism exists in relation to the languages involved and their situation. For multilingual literatures, this applies to an even greater extent: research on these literatures, and analysis of them, requires in-depth knowledge of all the relevant cultural and literary traditions and their political contexts.

\section{Works cited}

Bendix, Regina. In Search of Authenticity: The Formation of Folklore Studies. Madison: University of Wisconsin Press, 2009.

Blommaert, Jan, Sirpa Leppänen, and Massimiliano Spotti. “Endangering Multilingualism.” Dangerous Multilingualism: Northern Perspectives on Order, Purity, and Normality. Ed. Blommaert, Leppänen, Päivi Pahta, and Tiina Räisänen. Houndmills: Palgrave Macmillan, 2012. 1-24.

Brunstad, Endre. "Standard Language and Linguistic Purism.” Sociolinguistica 17.1 (2003): 52-70. 
Contra [Kõnnula, Margus]. “Taivaretel.” Võro kirändüse kodoleht. Võro Institute, n.d. http:// wi.ee/voro/kiranigu/contra/ (5 August 2018).

Garland, Jennifer. "The Minority Language and the Cosmopolitan Speaker: Ideologies of Irish Language Learners.” PhD thesis. University of California, Santa Barbara, 2008.

Kamusella, Tomasz. The Politics of Language and Nationalism in Modern Central Europe. Houndmills and New York: Palgrave Macmillan, 2009.

Koreinik, Kadri. The Võro Language in Estonia: ELDIA Case-Specific Report. Mainz: ELDIA, 2013. Studies in European Language Diversity 23. http://phaidra.univie.ac.at/o:308888 (5 August 2018).

Lee, Emily S. "The Epistemology of the Question of Authenticity, in Place of Strategic Essentialism." Hypatia 26.2 (2011): 258-279.

Leerssen, Joep. "Notes towards a Definition of Romantic Nationalism." Romantik: Journal for the Study of Romanticisms 2 (2013): 9-35.

Milroy, James. "Language Ideologies and the Consequences of Standardization." Journal of Sociolinguistics 5.4 (2001): 530-555.

Moshnikova, Olga. “Šipainik.” opastajat.net. n.d. http://opastajat.net/luvekkua/muut/olmo. html (5 August 2018).

Nilsen-Børsskog, Alf. Kuosuvaaran takana. n.p.: Iđut, 2004.

Nilsson, Magnus. "Literature in Multicultural and Multilingual Sweden: The Birth and Death of the Immigrant Writer." Literature, Language, and Multiculturalism in Scandinavia and the Low Countries. Ed. Wolfgang Behschnitt, Sarah De Mul, and Liesbeth Minnaard. Amsterdam: Rodopi, 2013. 41-62.

Pohjanen, Bengt. Jopparikuninkhaan poika. Överkalix: Barents, 2009.

Puura, Ulriikka, Heini Karjalainen, Nina Zayceva, and Riho Grünthal. Veps in Russia: ELDIA Case-Specific Report. Contributions by Anneli Sarhimaa and Eva Kühhirt. Mainz: ELDIA, 2013. Studies in European Language Diversity 25. http://phaidra.univie.ac.at/o:315545 (5 August 2018).

Scheller, Elisabeth. "The Saami Language Situation in Russia." Ethnic and Linguistic Context of Identity: Finno-Ugric Minorities. Ed. Riho Grünthal and Magdolna Kovács. Helsinki: Finno-Ugrian Society, 2011. Uralica Helsingiensia 5. 79-96.

Sternberg, Meir. "Polylingualism as Reality and Translation as Mimesis." Poetics Today 2.4 (1981): 221-239.

Thomas, George. Linguistic Purism. London and New York: Longman, 1991.

Verschik, Anna. "Mitmekeelsus kui ideaal ja loovuse allikas." Kiili rikkus ja elojoud = Keelte paljusus ja elujõud = Diversity and Vitality of Languages. Ed. Jüvä Sullõv. Võro: Võro Instituut, 2013. Publications of Võro Institute 27. 11-29.

Зайцева, М. И., and М. И. Муллонен [Zajceva, М. I., and M. I. Mullonen]. Образцы вепсской речи. Leningrad: Nauka, 1969.

Johanna Laakso has held the chair of Finno-Ugric Language Studies at the University of Vienna since 2000. Her research interests include historical linguistics, multilingualism and language contact, minority language issues, and gender linguistics. 
